\title{
Spatial variability of soil potassium in sugarcane areas subjected to the application of vinasse
}

\author{
LAÉRCIO A. DE CARVALHO ${ }^{1}$, ISMAEL MEURER ${ }^{2}$, CARLOS A. DA SILVA JUNIOR ${ }^{3}$, \\ CRISTIANE F.B. SANTOS ${ }^{1}$ and PAULO L. LIBARDI ${ }^{2}$ \\ ${ }^{1}$ Universidade Estadual de Mato Grosso do Sul/UEMS, Unidade de Dourados, \\ Cidade Universitária de Dourados, Zona Rural, Caixa Postal 351, 79804-970 Dourados, MS, Brasil \\ ${ }^{2}$ Escola Superior de Agricultura "Luiz de Queiroz", Universidade de São Paulo, \\ Av. Pádua Dias, 11, 13418-900 Piracicaba, SP, Brasil \\ ${ }^{3}$ Universidade Estadual de Maringá/UEM, Av. Colombo, 5790, Zona 7, 87020-900 Maringá, PR, Brasil
}

Manuscript received on August 20, 2013; accepted for publication on March 11, 2014

\begin{abstract}
When deposited on land the vinasse can promote improvement in fertility, however, often fertilizer application occurs in areas considered homogeneous, without taking into account the variability of the soil. The objective of this study was to evaluate the effect of vinasse application on potassium content in two classes of soils cultivated with sugarcane, and characterize the spatial variability of soil using geostatistical techniques. In the 2010 and 2011 crop year, soil samples were collected from an experimental grid at 0-0.2 and 0.2-0.4 m depth in three soils cultivated with sugarcane, totaling 90 samplings in each grid, for the determination of $\mathrm{pH}$, calcium $(\mathrm{Ca})$, magnesium $(\mathrm{Mg})$, potassium $(\mathrm{K})$, phosphorus $(\mathrm{P})$, aluminum $(\mathrm{Al})$ and potential acidity $(\mathrm{H}+\mathrm{Al})$. The data have been submitted to analysis of descriptive statistics and the $\mathrm{K}$ attribute was subjected to geostatistical analysis. The coefficient of variation indicated medium and high variability of $\mathrm{K}$ for the three soils. The results showed that the spatial dependence of K increased in depth to FRce and decreased to PHlv, indicating that the attribute could have followed the pattern of distribution of clay in depth. The investigation of the spatial variability of $\mathrm{K}$ on the surface and subsurface soils provided the definition of management zones with different levels of fertility, which can be organized into sub-areas for a more efficient management of the resources and the environment.
\end{abstract}

Key words: Geostatistics, Saccharum officinarum, semivariogram, soil fertility.

\section{INTRODUCTION}

In 2007, increase in the sugarcane industry in Brazil, became the world's largest producer of sugarcane and its derivatives. Currently the production area continues to expand, especially in central-western Brazil, allocating $55 \%$ of production to manufacturing ethanol and $45 \%$ to manufacturing of sugar (Kohlhepp 2010).

Correspondence to: Carlos Antonio da Silva Junior

E-mail: carlos-junior89@hotmail.com
Parallel to increased production of ethanol is also the increase of the production of vinasse, a waste liquid coming from the distillation process thereof. According to Andrade and Diniz (2007), vinasse is generated at the rate of 13 liters per liter of ethanol, whose composition is quite variable, with about 2 to $6 \%$ of solid constituents, in which the organic matter is highlighted in greater quantity which assists in improving the sum of bases and results in an effect 
on the consistency, aeration, temperature, and permeability, reducing the plasticity and cohesion of the soil, favoring agricultural operations. In terms of minerals have appreciable amounts of cations such as $\mathrm{K}$ in larger quantities, followed by Ca, N and Mg (Silva et al. 2005).

The opposed by the effects contaminants in soil and groundwater, in most cases is the final destination of vinasse. In view of the results obtained and the knowledge acquired from tests that contribute to positive effects on the economy of agriculture associated with mineral fertilizers, the economic value gained makes the hypothesis of divergent polluter (Leite 1999).

It is known that when deposited on land the vinasse can promote improvement in fertility, but the amounts should not exceed its capacity to retain ions, since this has unbalanced quantities of mineral and organic elements and can cause leaching of various of these ions, particularly nitrate and potassium (Silva et al. 2007).

Often fertilizer application occur in areas considered homogeneous, without taking into account the variability of the soil. When soil sampling is performed, one should always consider their spatial variability, enabling more detailed and representative of the area, which allows dosages to be calculated according to the characteristics of each soil regionalized.

Studies conducted by Corá et al. (2004) in sugar cane crop demonstrated that the attributes $\mathrm{K}$ and $\mathrm{OM}$ presented great amplitude in the surface layer of a Oxisol, suggesting that the uneven application of vinasse might be an additional cause of their variability and lower spatial continuity, compared to the deeper layer. Dalchiavon et al. (2013) have recently shown that plant population and soil organic matter content, evidenced spatial correlations with sugarcane productivity, indicating site-specific management that are strongly associated with sugarcane production. Thus, the geostatistical analysis becomes an important tool in the study of spatial variability of soil properties, supporting the decision on the management of specific sites (Marques Júnior et al. 2008, Carvalho et al. 2012). This strategy will make it possible to reduce costs, fertilizer use, and environmental pressure.

The objective of this research was to evaluate the effect of vinasse in the potassium in two classes of soil cultivated with sugarcane for two consecutive years, at $0-0.2$ and $0.2-0.4 \mathrm{~m}$ and characterize the spatial variability of this element in the soil using the techniques of geostatistics.

\section{MATERIALS AND METHODS}

\section{STUDY AREA}

The study area is located in a region belonging to Sugar and Ethanol Mill in Rio Brilhante, state of Mato Grosso do Sul, Brazil, at the geographical coordinates of Lat. $21^{\circ} 50^{\prime} \mathrm{S}$ and Long. 53 $57^{\prime} \mathrm{W}$ (Fig. 1), at an average altitude of $312 \mathrm{~m}$, with the predominant climate type Aw, according to the Köppen-Geiger.

The study was conducted in three areas with distinct soil classes (Table I), classified according to the FAO methodology (IUSS Working Group WRB 2006). The soil classes were denominated in the following order: Rhodic Ferralsols (FR), Rhodic Ferralsols Clayic (FRce) and Luvic Phaeozems (PHlv).

The three soils studied were prepared in 2005 by heavy disking followed by plowing to incorporate lime ( 1 ton $\left.\mathrm{ha}^{-1}\right)$ and gypsum $\left(0.5\right.$ ton $\left.\mathrm{ha}^{-1}\right)$. The planting fertilization was composed of $50 \mathrm{~kg} \mathrm{ha}^{-1}$ $\mathrm{N}, 150 \mathrm{~kg} \mathrm{ha}^{-1} \mathrm{P}$ and $50 \mathrm{~kg} \mathrm{ha}^{-1} \mathrm{~K}$. After the first cut, topdressing with vinasse was performed as a source of $\mathrm{N}$ and $\mathrm{K}$ at a dose of $200 \mathrm{~m}^{3} \mathrm{ha}^{-1}$ by using a self-propelled sprayer.

The experimental desing in each of the three soils was a 90 points grid, which was drafted on 2010 crop year with $160 \mathrm{~m}$ length and $163.8 \mathrm{~m}$ width $\left(26.208 \mathrm{~m}^{2}\right)$. Already in the 2011 crop year, the grid was configured with $180 \mathrm{~m}$ length and $145.6 \mathrm{~m}$ width $\left(26.208 \mathrm{~m}^{2}\right)$. In both grids, points were spaced $18.2 \mathrm{~m}$ from their neighbor on the $\mathrm{X}$ axis and $20 \mathrm{~m}$ on $\mathrm{Y}$ axis. 


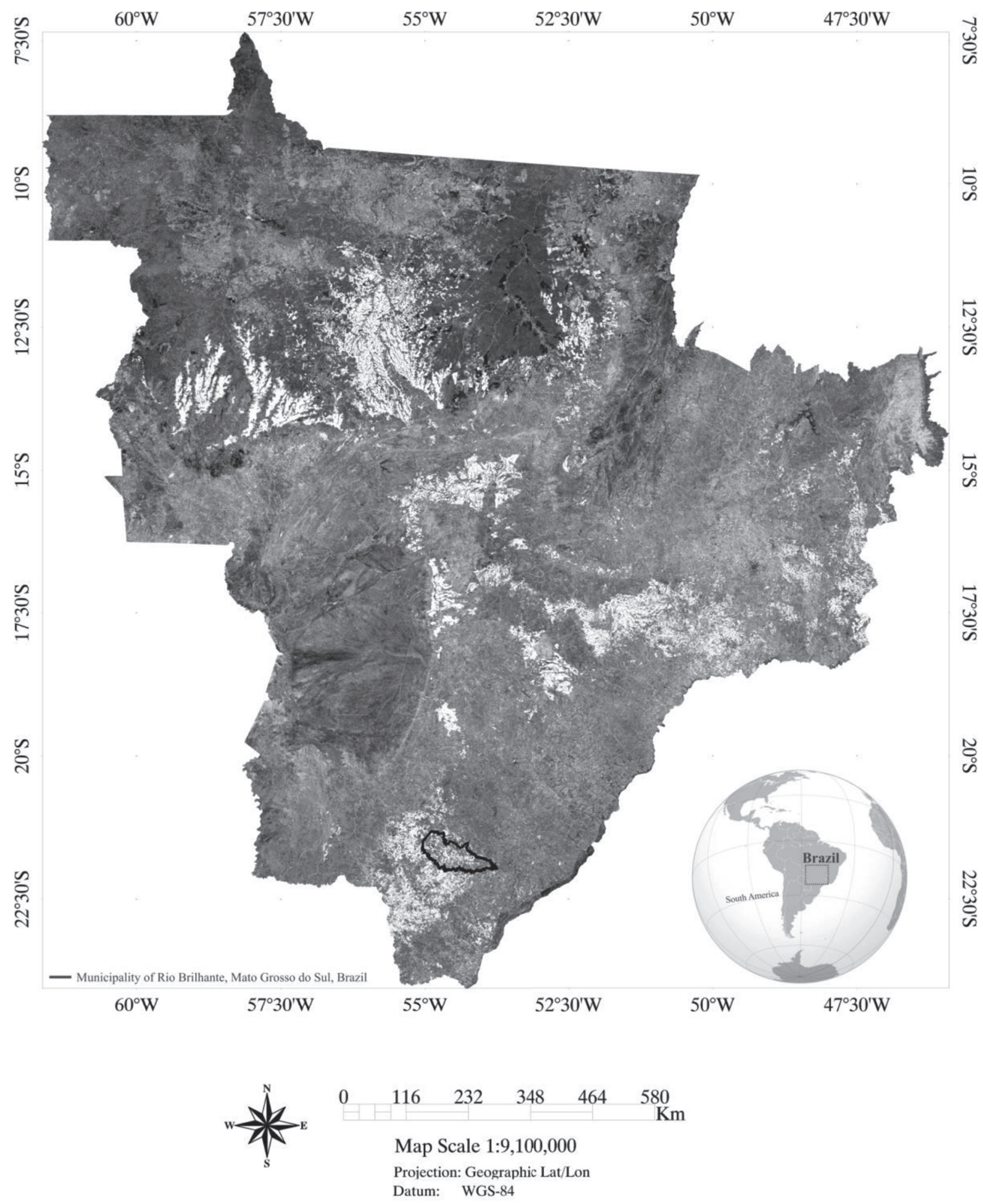

Figure 1 - Study area - central-western region of Brazil, Rio Brilhante, state of Mato Grosso do Sul, Brazil. Picture representation of the product sensor-system (EVI-MODIS/Terra). 
TABLE I

Particle size and textural class of two layers of three soils.

\begin{tabular}{ccccccc}
\hline Soil & Clay & $\begin{array}{c}\text { Silt } \\
\text { - }\end{array}$ & $\begin{array}{c}\text { Sand } \\
\text { TOC }\end{array}$ & $\begin{array}{c}\text { TOC } \\
\mathbf{m g ~ k g}\end{array}$ & $\begin{array}{c}\text { Pd } \\
\mathbf{g ~ c m}^{-3}\end{array}$ & Textural Class \\
\hline FR & 29.2 & 6.9 & 63.9 & 13,010 & 2.74 & Loamy-sandy-clay \\
FRce & 50.1 & 7.9 & 42.0 & 15,730 & 2.88 & Clayey \\
PHlv & 11.2 & 4.7 & 84.1 & 9,990 & 2.72 & Loamy-sandy \\
\hline FR & 36.5 & 5.9 & 57.6 & 6,350 & 2.77 & Sandy-clay \\
FRce & 58.9 & 9.2 & 32.0 & 8,290 & 2.91 & Clayey \\
PHlv & 20.1 & 3.9 & 76.0 & 4,100 & 2.74 & Loamy-sandy-clay \\
\hline
\end{tabular}

$\mathrm{TOC}=$ organic carbon, $\mathrm{Pd}=$ particle density.

Sampling was conducted after harvest of the $4^{\text {th }}$ (February 2010) and 5th (February 2011) crop of sugarcane in the mechanized harvesting system without previous straw burning. Undeformed soil samples were collected from the 0-0.2 and 0.2-0.4 $\mathrm{m}$ layer, between plant rows, using steel cylinders of $0.05 \mathrm{~m}$ diameter and $0.05 \mathrm{~m}$ in height. Each steel cylinder containing a soil sample was protected with aluminum foil and stored in a box for transport to the laboratory. In all, 1080 samples were taken, 540 per crop year, 180 per soil class and 90 per layer.

\section{LABORATORY ANALYSIS}

The samples were air dried, deformed and passed sieves with apertures of $2 \mathrm{~mm}$ to obtain the air-dried soil. Later, there were chemical analyzes of the soil in the Soils Laboratory in Embrapa, MS, Brazil (Table II), according to the methodology described by EMBRAPA (2005).

The analyses carried out for chemical characterization of the two types of soil studied, were $\mathrm{pH}$ in soil water, $\mathrm{pH}$ in solution of $\mathrm{CaCl}_{2}\left(0.01 \mathrm{~mol} \mathrm{~L}^{-1}\right)$, calcium $(\mathrm{Ca})$ and magnesium $(\mathrm{Mg})$ were exchangeable extracted with $\mathrm{KCl} 1 \mathrm{~mol} \mathrm{~L}^{-1}$, were determined by atomic absorption spectrometry (EMBRAPA 2005).

The potassium exchangeable $(\mathrm{K})$ and the phosphorus $(\mathrm{P})$ were extracted available soil with Mehlich $^{-1}$ solution $(0.05 \mathrm{M} \mathrm{HCl}+0.0125 \mathrm{M}$ $\mathrm{H}_{2} \mathrm{SO}_{4} 0.0125$ ), and $\mathrm{K}$ content was determined by photometry flame and $\mathrm{P}$ content by colorimetry. Aluminum (Al) was extracted with $1 \mathrm{M} \mathrm{KCl}$ and determined by titration with $0.01 \mathrm{M} \mathrm{NaOH}$. The potential acidity $(\mathrm{H}+\mathrm{Al})$ was determined with extract of calcium acetate $\left[\mathrm{Ca}(\mathrm{CH} 3 \mathrm{COO})_{2}\right] 1 \mathrm{M}$ at $\mathrm{pH} 7.0$ and then quantified by titration with sodium hydroxide solution $(\mathrm{NaOH})$. Also was to calculate the sum of bases $\left(\mathrm{SB}=\mathrm{Ca}^{2+}+\mathrm{Mg}^{2+}+\mathrm{K}^{+}\right)$and cation exchange capacity (CEC at $\mathrm{pH} 7.0\left(\mathrm{Ca}^{2+}+\mathrm{Mg}^{2+}+\right.$ $\left.\mathrm{K}^{+}+\mathrm{H}^{+}+\mathrm{Al}^{3+}\right)$ ). Based on the analysis of the cation exchange capacity, was to calculate the percentage of potassium in the soil (EMBRAPA 2005).

The vinasse used in the three studied soils was provided by the own sugarcane mill. Table III shows chemical composition of the dilute vinasse, determined by the sugarcane mill laboratory.

\section{DATA ANALYSES}

A descriptive statistical analysis was performed with the help of the program BioEstat, through the following measures sampling: mean, median, standard deviation, maximum and minimum, interquartile range, coefficient of skewness and kurtosis, coefficient of variation, variance and parametric test normality Shapiro-Wilk test at $5 \%$ probability.

Geostatistics has been used to check the data, and if so, to quantify the degree of spatial dependence of the data generated by the application of $\mathrm{K}$ in the soil, which was made from the set of functions to 
TABLE II

Chemical characterization of soil on the crop years 2010 and 2011, in 0-0.2 and 0.2-0.4 m depth.

\begin{tabular}{|c|c|c|c|c|c|c|c|c|c|c|}
\hline Soil & $\begin{array}{c}\mathrm{pH} \\
\mathrm{H}_{2} \mathrm{O} \\
\end{array}$ & $\begin{array}{c}\mathrm{pH} \\
\mathrm{CaCl}_{2} \\
\end{array}$ & $\mathbf{P}$ & Al & $\mathrm{Ca}$ & Mg & $\begin{array}{l}\mathrm{H}+\mathrm{Al} \\
\mathrm{n}^{-3}-\cdots\end{array}$ & $\mathbf{K}$ & SB & $\begin{array}{l}\mathrm{CEC}_{\mathrm{pH} 7} \\
-\end{array}$ \\
\hline \multicolumn{11}{|c|}{$0-0.2 \mathrm{~m}(2010)$} \\
\hline FR & 6.6 & 6.0 & 0.0055 & 0 & 1.28 & 0.24 & 0.02 & 1.33 & 2.85 & 2.87 \\
\hline FRce & 5.1 & 4.3 & 0.0024 & 0.11 & 0.36 & 0.12 & 0.16 & 1.45 & 1.93 & 2.09 \\
\hline PHlv & 6.5 & 5.9 & 0.0082 & 0 & 1.04 & 0.12 & 0.02 & 0.74 & 1.90 & 1.92 \\
\hline \multicolumn{11}{|c|}{$0.2-0.4 \mathrm{~m}(2010)$} \\
\hline FR & 6.6 & 6.0 & 0.0123 & 0 & 1.36 & 0.19 & 0.02 & 1.45 & 3.00 & 3.02 \\
\hline FRce & 5.2 & 4.4 & 0.0012 & 0.13 & 0.36 & 0.12 & 0.18 & 0.51 & 0.99 & 1.17 \\
\hline PHlv & 6.4 & 5.8 & 0.0046 & 0 & 1.08 & 0.09 & 0.02 & 0.59 & 1.76 & 1.78 \\
\hline \multicolumn{11}{|c|}{$0-0.2 m$} \\
\hline FR & 6.7 & 6.1 & 0.0093 & 0 & 1.36 & 0.29 & 0.02 & 1.41 & 3.06 & 3.08 \\
\hline FRce & 5.9 & 5.2 & 0.0052 & 0.27 & 0.96 & 0.31 & 0.31 & 2.70 & 3.97 & 4.28 \\
\hline PHlv & 6.3 & 5.7 & 0.0075 & 0 & 1.04 & 0.17 & 0.02 & 1.33 & 2.54 & 2.56 \\
\hline \multicolumn{11}{|c|}{$0.2-0.4 m(2011)$} \\
\hline FR & 6.8 & 6.2 & 0.0077 & 0 & 1.40 & 0.27 & 0.02 & 1.17 & 2.84 & 2.86 \\
\hline FRce & 5.1 & 4.3 & 0.0020 & 0.13 & 0.44 & 0.14 & 0.18 & 1.05 & 1.63 & 1.81 \\
\hline PHlv & 6.4 & 5.8 & 0.0024 & 0 & 1.08 & 0.14 & 0.02 & 0.47 & 1.69 & 1.71 \\
\hline
\end{tabular}

TABLE III

Average chemical composition of the dilute vinasse applied.

\begin{tabular}{ccc}
\hline Parameters & Unit & Concentration \\
\hline $\mathrm{pH}$ & --- & 4.80 \\
Carbon & $\mathrm{mg} \mathrm{kg}^{-1} \mathrm{C}$ & 4.150 \\
Nitrogen & $\mathrm{mg} \mathrm{kg}^{-1} \mathrm{~N}$ & 300 \\
Phosphorus & $\mathrm{mg} \mathrm{kg}^{-1} \mathrm{P}_{2} \mathrm{O}_{5}$ & 70 \\
Potassium & $\mathrm{mg} \mathrm{kg}^{-1} \mathrm{~K}_{2} \mathrm{O}$ & 1.460 \\
Calcium & $\mathrm{mg} \mathrm{kg}^{-1} \mathrm{CaO}$ & 360 \\
Magnesium & $\mathrm{mg} \mathrm{kg}^{-1} \mathrm{MgO}^{-1}$ & 30 \\
Sulfate & $\mathrm{mg} \mathrm{kg}^{-1} \mathrm{SO}_{4}^{-2}$ & 610 \\
Copper & $\mathrm{mg} \mathrm{kg}^{-1} \mathrm{Cu}^{-2}$ & 0.75 \\
Iron & $\mathrm{mg} \mathrm{kg}^{-1} \mathrm{Fe}$ & 18.85 \\
Manganese & $\mathrm{mg} \mathrm{kg}^{-1} \mathrm{Mn}$ & 1.90 \\
Zinc & $\mathrm{mg} \mathrm{kg}^{-1} \mathrm{Zn}$ & 1.15 \\
\hline
\end{tabular}

theoretical models of experimental semivariograms based the assumption of stationarity assumption intrinsic and may be defined by Formula 1:

$$
\gamma(\mathrm{h})=1 / 2 \mathrm{E}\left\{\mathrm{Z}\left(\mathrm{x}_{1}\right)-\mathrm{Z}\left(\mathrm{x}_{1}+\mathrm{h}\right)\right\}^{2}
$$

and estimated by Formula 2:

$$
\gamma^{*}(\mathrm{~h})=\frac{1}{2 \mathrm{~N}(\mathrm{~h})} \sum_{\mathrm{i}=1}^{\mathrm{N}(\mathrm{h})}\left\{\mathrm{Z}\left(\mathrm{x}_{1}\right)-\mathrm{Z}\left(\mathrm{x}_{1}+\mathrm{h}\right)\right\}^{2}
$$

where $\gamma^{*}(h)$ is the experimental semivariogram, $\mathrm{Z}$ (xi) are the experimental values at points xi, where data are available $x i$ as in both $x i+h$, and $N(h)$ is the number of pairs experimental data separated by a distance $h$ (Vieira et al. 1983). The semivariogram helps to interpret the variability of the phenomenon in space.

To analyze the spatial dependence index (SDI) was used compared to $\mathrm{C} 0 /(\mathrm{C} 0+\mathrm{C} 1)$ and the 
intervals proposed by Cambardela et al. (1994), who considered the weak spatial dependence (SDI $>75 \%$ ), moderate $(25 \% \leq \mathrm{SDI} \leq 75 \%)$ and strong $(\mathrm{SDI}<25 \%)$.

The graph of $\gamma^{*}(\mathrm{~h})$ versus the corresponding values of $h$, called semivariogram is a function of the vector $\mathrm{h}$, and therefore depends on both the magnitude and direction of $h$ (Fig. 2)

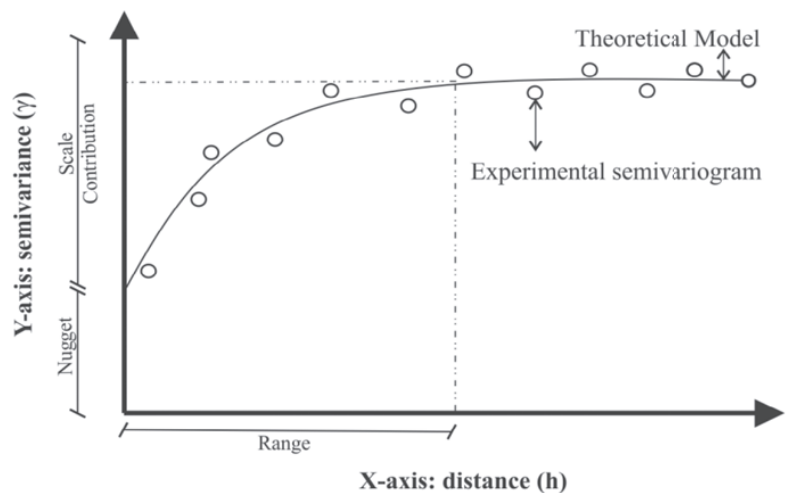

Figure 2 - Experimental semivariogram - theoretical graphical representation.

Mathematical models must be adjusted to the semivariograms, which let you view the nature of the spatial variation of variables, and are needed for other applications, e.g. kriging. Mathematical models Gaussian (Formula 3) exponential (Formula 4) and linear (Formula 5) were adjusted to semivariograms:

$\gamma(\mathrm{h})=\mathrm{C}_{0}+\mathrm{C}_{1}\left[1-\exp \left(-3\left(\frac{\mathrm{h}}{\mathrm{a}}\right)^{2}\right)\right], 0<\mathrm{h}<\mathrm{d}$

$\gamma(\mathrm{h})=\mathrm{C}_{0}+\mathrm{C}_{1}\left[1-\exp \left(-3\left(\frac{\mathrm{h}}{\mathrm{a}}\right)\right)\right], 0<\mathrm{h}<\mathrm{d}$

Where $\mathrm{d}$ is the maximum distance at which the semivariogram is defined.

$$
\gamma(\mathrm{h})=|h|
$$

In the setting of theoretical models to experimental semivariograms were determined with the software GS+ (Robertson 1998), the coefficients nugget effect $(\mathrm{C} 0)$, sill $(\mathrm{C} 0+\mathrm{C} 1)$, structural variance $(\mathrm{C} 1)$ and range (a). This software applies the method of least squares and adopts as criteria for selecting the highest value of $\mathrm{R}^{2}$ (coefficient of determination) and the lowest SQR (sum of squared residuals) (Guimarães 2000).

With the proven spatial dependence, was to use the method of ordinary kriging interpolation to estimate values at unmeasured locations (Vieira 2000).

\section{RESULTS AND DISCUSSION}

The analysis of the data (Tables IV and V) indicates that the mean and median values are close to each other. According to Cambardella et al. (1994), this demonstrates that the distribution of the data tends to be symmetrical, with the exception of the values of $\mathrm{K}$ in the soil FRce and PHlv at depth 0-0.2, 0.2-0.4 and $0.2-0.4 \mathrm{~m}$, respectively, in the two seasons studied.

The Shapiro-Wilk test $(\mathrm{p}>0.05)$, indicated a normal distribution of the variable $\mathrm{K}$ only in the second tier of FR (crop year 2011), keeping asymmetric distribution in the other soils and depths in the years 2010 and 2011 season (Tables IV and V).

The coefficients of skewness and kurtosis smaller than 1 (FR and layer of 0-0.2 $\mathrm{m}$ from the PHlv in two crops), show a tendency to normal, once these parameters are more sensitive to outliers, since the deviations between the mean value are elevated to the third and fourth, respectively (Sanchez et al. 2009). However, these coefficients had values far away from zero in FRce, which according to Gonçalves et al. (2001), may indicate that the distribution tails contain very long, compromising the geostatistical.

According to the classification of the coefficient of variation (C.V.) proposed by Warrick and Nielsen (1980), the variable K showed high variability in both depths of FRce and in the 0.2$0.4 \mathrm{~m}$ for FR two studied seasons. Data researched by Marques Júnior et al. (2008) confirm the high variability observed for the potassium element in the soil in sugarcane areas fertirrigated. In the PHlv it is classified as C.V. values of average variability for the variable $\mathrm{K}$ in the soil. 
TABLE IV

Descriptive statistical analysis of $\mathrm{K}$ variable

(\%) at both depths on FR, FRce and PHlv

for the crop year 2010.

\begin{tabular}{|c|c|c|c|c|c|c|}
\hline Depth & $0-0.2 \mathrm{~m}$ & $0.2-0.4 \mathrm{~m}$ & $0-0.2 \mathrm{~m}$ & $0.2-0.4 \mathrm{~m}$ & $0-0.2 \mathrm{~m}$ & $0.2-0.4 \mathrm{~m}$ \\
\hline Measurements Statistics/Soils & \multicolumn{2}{|c|}{ FR } & \multicolumn{2}{|c|}{ FRce } & \multicolumn{2}{|c|}{ PHlv } \\
\hline Mean & 5.20 & 4.12 & 2.94 & 2.16 & 3.17 & 2.75 \\
\hline Median & 4.99 & 4.02 & 2.23 & 1.47 & 3.14 & 2.34 \\
\hline Variance & 8.22 & 7.01 & 4.96 & 4.71 & 1.65 & 1.83 \\
\hline Standard deviation & 2.87 & 2.65 & 2.23 & 2.17 & 1.28 & 1.35 \\
\hline C.V. $(\%)$ & 55.12 & 64.32 & 75.87 & 100.27 & 40.53 & 49.19 \\
\hline Asymmetry & 0.83 & 0.88 & 2.63 & 3.62 & 0.70 & 1.48 \\
\hline Kurtosis & 0.61 & 0.81 & 8.09 & 16.15 & 0.23 & 2.48 \\
\hline W (p) & 0.00046 & 0.00009 & 0.00000 & 0.00000 & 0.00204 & 0.00000 \\
\hline
\end{tabular}

C.V. = Coefficient of Variation (\%); $\mathrm{W}=$ result of normality test of Shapiro-Wilk, $5 \%$ probability.

TABLE V

Descriptive statistical analysis of $K$ variable (\%) at both

depths on FR, FRce and PHIv for the crop year 2011.

\begin{tabular}{cccccccc}
\hline Depth & $\mathbf{0 - 0 . 2} \mathbf{~ m}$ & $\mathbf{0 . 2 - 0 . 4} \mathbf{~ m}$ & $\mathbf{0 - 0 . 2} \mathbf{~ m}$ & $\mathbf{0 . 2 - 0 . 4} \mathbf{~ m}$ & $\mathbf{0 - 0 . 2} \mathbf{~ m}$ & $\mathbf{0 . 2 - 0 . 4} \mathbf{~ m}$ \\
\hline Measurements Statistics/Soils & \multicolumn{2}{c}{ FR } & \multicolumn{2}{c}{ FRce } & \multicolumn{2}{c}{ PHlv } \\
\hline Mean & 5.71 & 4.14 & 6.86 & 3.86 & 5.16 & 2.41 \\
Median & 5.57 & 4.23 & 4.87 & 2.66 & 5.18 & 2.13 \\
Variance & 3.54 & 3.99 & 24.31 & 13.66 & 3.24 & 1.55 \\
Standard deviation & 1.88 & 2.00 & 4.93 & 3.70 & 1.80 & 1.24 \\
C.V. (\%) & 32.91 & 48.32 & 71.85 & 95.74 & 34.87 & 51.54 \\
Asymmetry & 0.91 & 0.31 & 1.67 & 2.68 & 0.49 & 1.39 \\
Kurtosis & 0.92 & -0.07 & 2.11 & 8.08 & 2.70 & 2.35 \\
W (p) & 0.00094 & 0.05891 & 0.00000 & 0.00000 & 0.00475 & 0.00000 \\
\hline
\end{tabular}

C.V. $=$ Coefficient of Variation (\%); $\mathrm{W}=$ result of normality test of Shapiro-Wilk, $5 \%$ probability.

According to Isaaks and Srivastava (1989), the normality of the data is not necessarily a requirement of geostatistics, being more important to note the occurrence of proportional effect on the mean and variance of the data is not contained in the study soils in order semivariograms with heights well defined. In this case, observing the levels of experimental semivariograms and modeled in Fig. 3 and Fig. 4, it is possible to verify the occurrence of proportional effect, except for Fig. 3D (nugget effect), $3 \mathrm{C}$ and $3 \mathrm{~F}$ (tendency to nugget effect).
Table VI presents the models and parameters adjusted semivariograms for the variable $\mathrm{K}$ in the three soils, two depths and two crop years studied.

The results of geostatistical analysis (Table VI, Figs. 3 and 4) indicated that the variable K showed spatial dependence in FR, 0-0.2 $\mathrm{m}$ depth, for the crop years 2010 and 2011, FRce, both depths in the 2010 season and 0.2-0.4 m depth in the crop year 2011, and in PHlv at both depths and harvests.

There was no spatial dependence in FR, depth 0.2-0.4 $\mathrm{m}$ and two studied seasons; and in FRce, 0-0.2 m depth in the 2011 crop (Table VI and Fig. 5). 

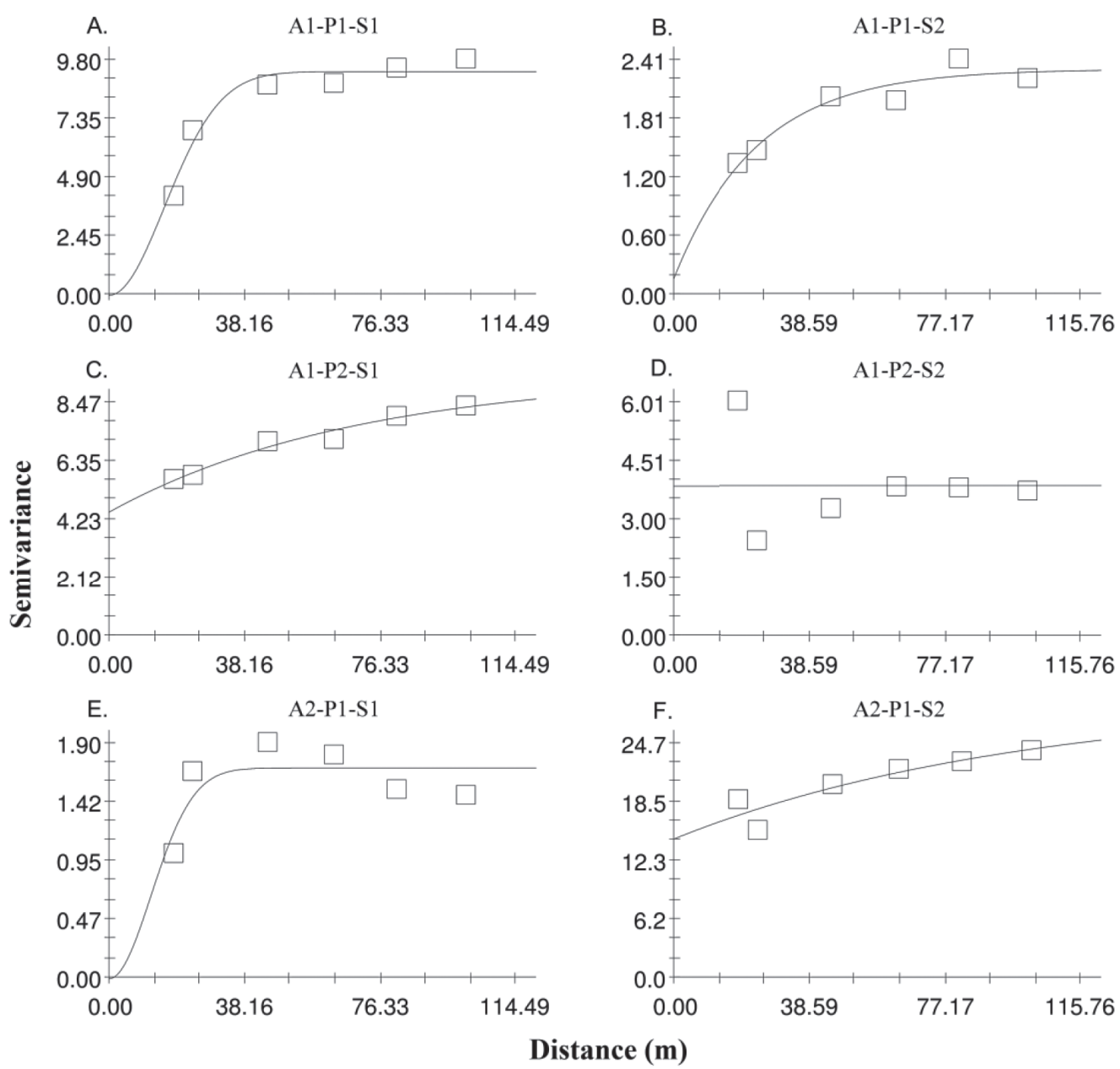

Figure 3 - Semivariograms experimental and modeled for the variable K in FR (A1), FRce (A2) and PHlv (A3) to the depths of 0-0.2 $\mathrm{m}$ (P1) and 0.2-0.4 m (P2), harvests of 2010 (S1) and 2011 (S2).

In such a situation it is said that the semivariogram nugget effect and showed the same trend effect. For these cases, it can be assumed that the distribution is completely random, there is independence between the samples and the statistical classic methods can be applied. Probably this case, the spatial dependency occurs at a distance greater than the distance between the sampling points used (Vieira 2000).

Was revealed that the determinations made in the soils of the graphs E, G and K exhibited range value lower than the sampling distance used in relation to the range of spatial dependence (Table VI). According to Campos et al. (2008), this means that there is no correlation between these parameters, therefore, the quality estimate made points with kriging interpolation may be impaired, which can be taken as these areas hold the lowest coefficient of determination $\left(\mathrm{R}^{2}\right)$. However, other areas show a correlation between the measurements, allowing the interpolation technique satisfactorily.

As can be seen in Table VI, the models were fitted to the semivariogram models exponential, gaussian and linear in FR, exponential and gaussian in FRce and gaussian in PHlv. In general, the gaussian model was the most fit to express the spatial variability of the variable $\mathrm{K}$ in the soil, with $\mathrm{R}^{2}$ above $60 \%$ and low SQR. 

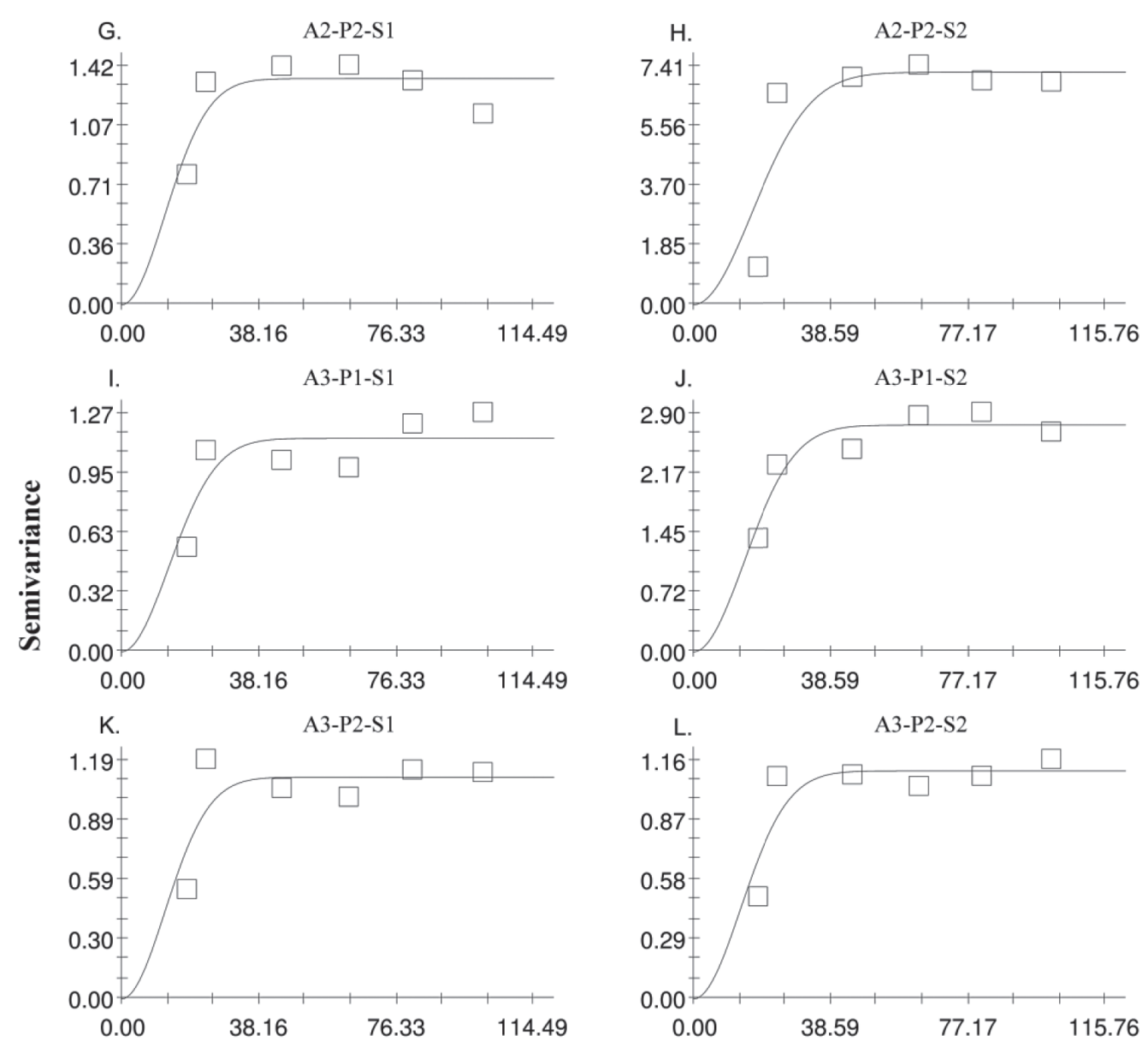

Distance (m)

Figure 4 - Semivariograms experimental and modeled for the variable K in FR (A1), FRce (A2) and PHlv (A3) to the depths of 0-0.2 m (P1) and 0.2-0.4 m (P2), harvests of 2010 (S1) and 2011 (S2).

TABLE VI

Parameters and models of semivariograms for the variable $\mathrm{K}(\%)$ in both layers of three soils on year crop 2010 and 2011.

\begin{tabular}{ccccccccc}
\hline \multirow{2}{*}{ Graphics } & Model & $\begin{array}{c}\mathbf{C}_{\mathbf{0}} \\
\mathbf{N E}\end{array}$ & $\begin{array}{c}\mathbf{C}_{\mathbf{0}}+\mathbf{C}_{\mathbf{1}} \\
\text { Scale }\end{array}$ & $\begin{array}{c}\mathbf{A 0} \\
\text { Range }\end{array}$ & $\begin{array}{c}\left(\mathbf{C o} /\left(\mathbf{C o}+\mathbf{C}_{\mathbf{1}}\right)\right) \mathbf{x 1 0 0} \\
\text { SDI }\end{array}$ & SDI & $\mathbf{R}^{\mathbf{2}}$ & $\mathbf{S Q R}^{\text {SQR }}$ \\
\hline A & Gaussian & 0.010 & 9.262 & 22.00 & 0.10 & Strong & 0.95 & 1.16 \\
B & Exponential & 0.169 & 2.301 & 23.70 & 7.34 & Strong & 0.90 & 0.07 \\
C & Exponential & 4.490 & 9.422 & 69.70 & 47.65 & Moderate & 0.90 & 0.16 \\
D & Linear & 3.848 & 3.848 & 100.24 & NE & NE & 0.04 & 6.95 \\
E & Gaussian & 0.001 & 1.689 & 16.70 & 0.06 & Strong & 0.60 & 0.20 \\
F & Exponential & 14.570 & 29.150 & 96.80 & 49.98 & Moderate & 0.83 & 7.91 \\
G & Gaussian & 0.001 & 1.342 & 17.00 & 0.07 & Strong & 0.66 & 0.11 \\
H & Gaussian & 0.010 & 7.174 & 23.20 & 0.14 & Strong & 0.73 & 8.32 \\
I & Gaussian & 0.001 & 1.127 & 18.50 & 0.09 & Strong & 0.66 & 0.11 \\
J & Gaussian & 0.001 & 2.738 & 20.00 & 0.04 & Strong & 0.88 & 0.19 \\
K & Gaussian & 0.001 & 1.098 & 17.10 & 0.10 & Strong & 0.59 & 0.12 \\
L & Gaussian & 0.001 & 1.101 & 18.70 & 0.10 & Strong & 0.75 & 0.08 \\
\hline
\end{tabular}

$\mathrm{NE}=$ Nugget effect; SDI $=$ spatial dependence index . 
In part, the low coefficient of determination $\left(\mathrm{R}^{2}\right)$ found in models adjusting semivariogram may be due to the large range of values for the variable $\mathrm{K}$ in the soil, revealing the second Corá et al. (2004), the problems that occur when using the average of the attribute values as a basis for decision-making in chemical management of soil, or in some places the recommended dose of fertilizers is undersized, in others it will be appropriate and in others there may be excessive application. This results in economic losses, both for application as unnecessary by the imbalance between the amounts of nutrients which will be available to plants, besides the effect that dopant incorporation can lead on the environment.

Knowing that the vinasse can bring improvement in soil fertility because it contains cations such as $\mathrm{Ca}^{2+}, \mathrm{Mg}^{2+}$ and $\mathrm{K}^{+}$(Table III) and observing the chemical properties in the two crops studied (Table II), can be denoted who hears increase in the sum of bases 9.2, 59.7 and $9.6 \%$ for FR, FRce and PHlv, respectively, in the layer of 0-0.2 increase of 6.7, 22.3 and $5 \%$ for FR, FRce and PHlv, respectively, on the layer of $0.2-0.4 \mathrm{~m}$. The FRce had the highest increase in the sum of bases in the application of vinasse, this may have been due to higher $\mathrm{K}$ ion adsorption by soils with high clay content.

In the analysis of the degree of spatial dependence of the variable $\mathrm{K}$ was used for the classification Cambardella et al. (1994), which considers spatial dependence strong semivariogram with nugget effect less than or equal to $25 \%$ of the baseline, moderate between 25 and $75 \%$ and poor when more than $75 \%$.

Analyzing the results of the degree of spatial dependence presented in Table VI, it was found that although there is the phenomenon of the nugget effect in some soils and depths, it can be observed that spatial dependence is strong in the first depth of FR, in both seasons, and moderate in the second depth on 2010 crop year. Already in FRce, the first layer showed strong spatial dependence in 2010 and moderate in 2011. The PHlv showed strong spatial dependence in both studied seasons and depths.
In Fig. 5 and 6 are shown the spatial distribution maps for variable $\mathrm{K}$ on the three studied soils obtained using the parameters of the fitted semivariograms (Table VI) for estimate unsampled values by kriging. The soils and depths that present nugget effect could not generate surface maps because the continuity of the variability was not detected. In depth $0-0.2 \mathrm{~m}$ of FR in the years 2010 and 2011 and $0-0,2 \mathrm{~m}$ and 0.2-0.4 $\mathrm{m}$ deep in FRce in 2010, it was found that the concentration of $\mathrm{K}$ was higher (Figs. 5A, 5B, 6E and $6 \mathrm{G}$, respectively). This was possibly due to the soil texture (FR and FRce), which has a high clay content, allowing greater sorption of K. According to Nicochelli et al. (2012), the clay minerals feature greater negative charge on the surface of particles, their ion exchange capacity (Table I) and therefore sorption is favored, which increases the retention of cations, such as $\mathrm{K}$.

Observing the distribution of potassium in depth on crop year 2010 (Figs. 5C, 5D for FRce and 6F, 6H for PHlv) and crop year 2011 (Figs. 6G and 6I to PHlv) it is found that the spatial variability increased on FRce and decreased slightly on PHlv with depth and with depth, such as can also be seen by the range values (Table VI). Apparently, the FRce and FR maps seem to maintain more coherence on the distribution of $\mathrm{K}$ in soil, comparing both layers, suggesting that the element follows the pattern of distribution of clay with depth.

The $\mathrm{K}$ ion did not present much interaction with the solid fraction of PHlv, since the cation exchange capacity of this soil was low, with few adsorption sites, which probably led the element into deeper layers.

Regarding the use of vinasse as a fertilizer in the production of sugarcane, there is a set of criteria and procedures which govern the application of vinasse in agricultural soil covered by Technical Standard P4.231 CETESB (Brazilian standard), which provides that the area to be used for soil application of vinasse must meet several criteria, including: the maximum concentration of potassium in the soil may not exceed $5 \%$ of the cation exchange capacity (CEC). 
Noticed it that all soils studied showed regions with $\mathrm{K}$ values above those allowed by the Technical Standard P4.231 CETESB (2006) Noting the maps of the spatial distribution for the variable $\mathrm{K}$ in the soil (Fig. 5 and 6). The maps indicate that the $\mathrm{K}$ above those allowed by the rules is concentrated in the central areas of the three soils studied, which makes it possible to divide the area into three parts, with different levels of fertility. Within each of these subareas can be defined several homogeneous areas of specific management, with the aim, in future, make the application of fertilizer at variable rates, providing a more efficient and economical crop management.

The information obtained through the survey of spatial variability and subsequent mapping of the soils that received vinasse application can be used for a variety of analyses at the interference areas. This allows application for specific locations of management differently, within the limits of K concentration in the soil without causing saturation of the element in the soil. Thus, the occurrence of an efficient management in the utilization of vinasse as a fertilizer together with cost reduction, increased productivity and provides preservation of the properties of the soil.

\section{CONCLUSION}

The descriptive statistical analysis and geostatistical methods were adequate to describe the dispersion of data and spatial dependence within the sampling interval of the variable $\mathrm{K}(\%)$ in the studied soils. The results showed that the spatial dependence of $\mathrm{K}$ increased in depth to FRce and decreased to PHlv, indicating that the attribute can have followed the pattern of distribution of clay in depth. The investigation of the spatial variability of $\mathrm{K}$ on the surface and subsurface soils provided the definition of management zones with different levels of fertility, which can be organized into sub-areas for a more efficient management of resources and the environment.

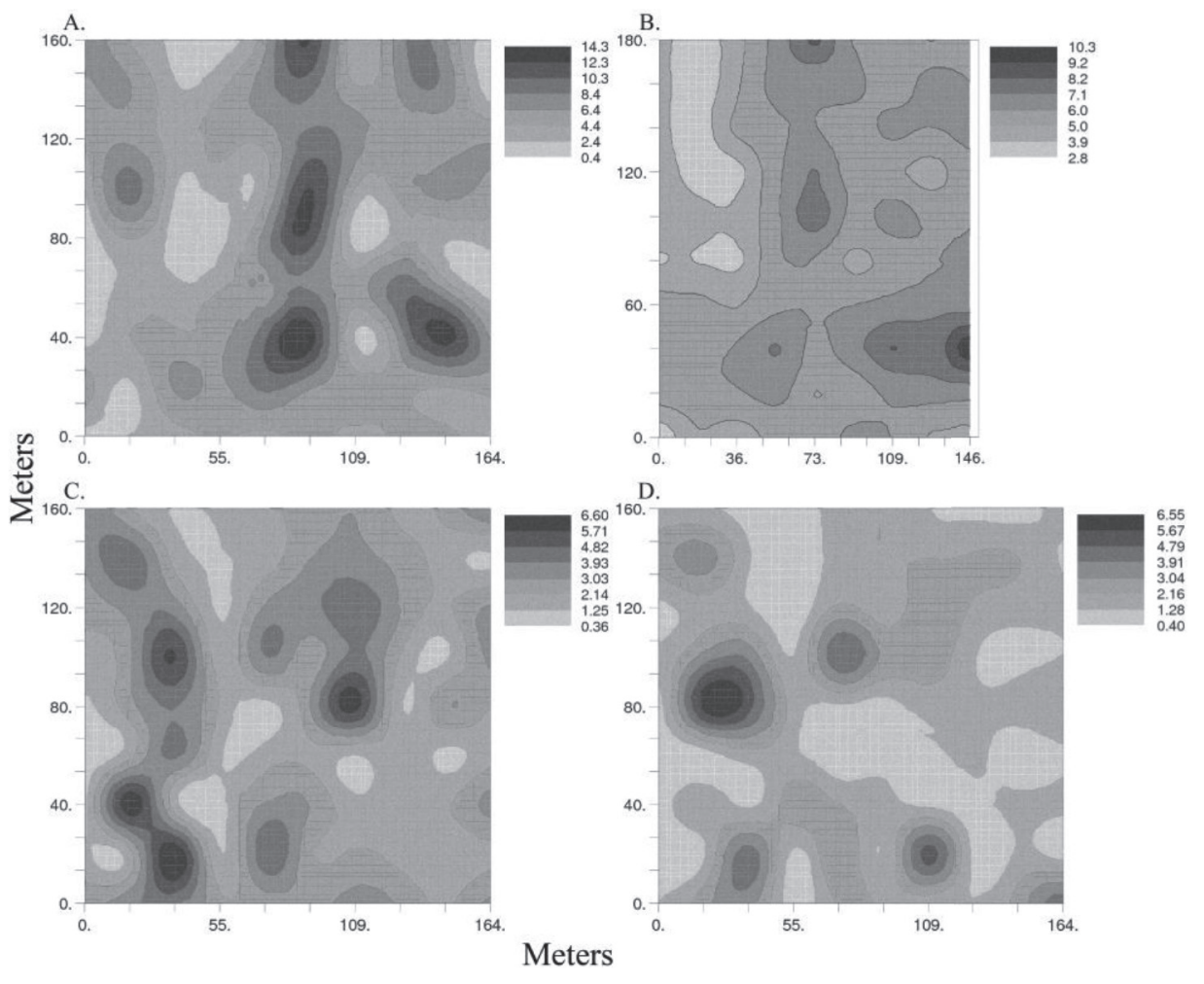

Figure 5 - Maps of the spatial distribution for the variable K (\%) of soil at 0-0.2 and 0.2-0.4 $\mathrm{m}$ in the three soils of crop years 2010 and 2011. 

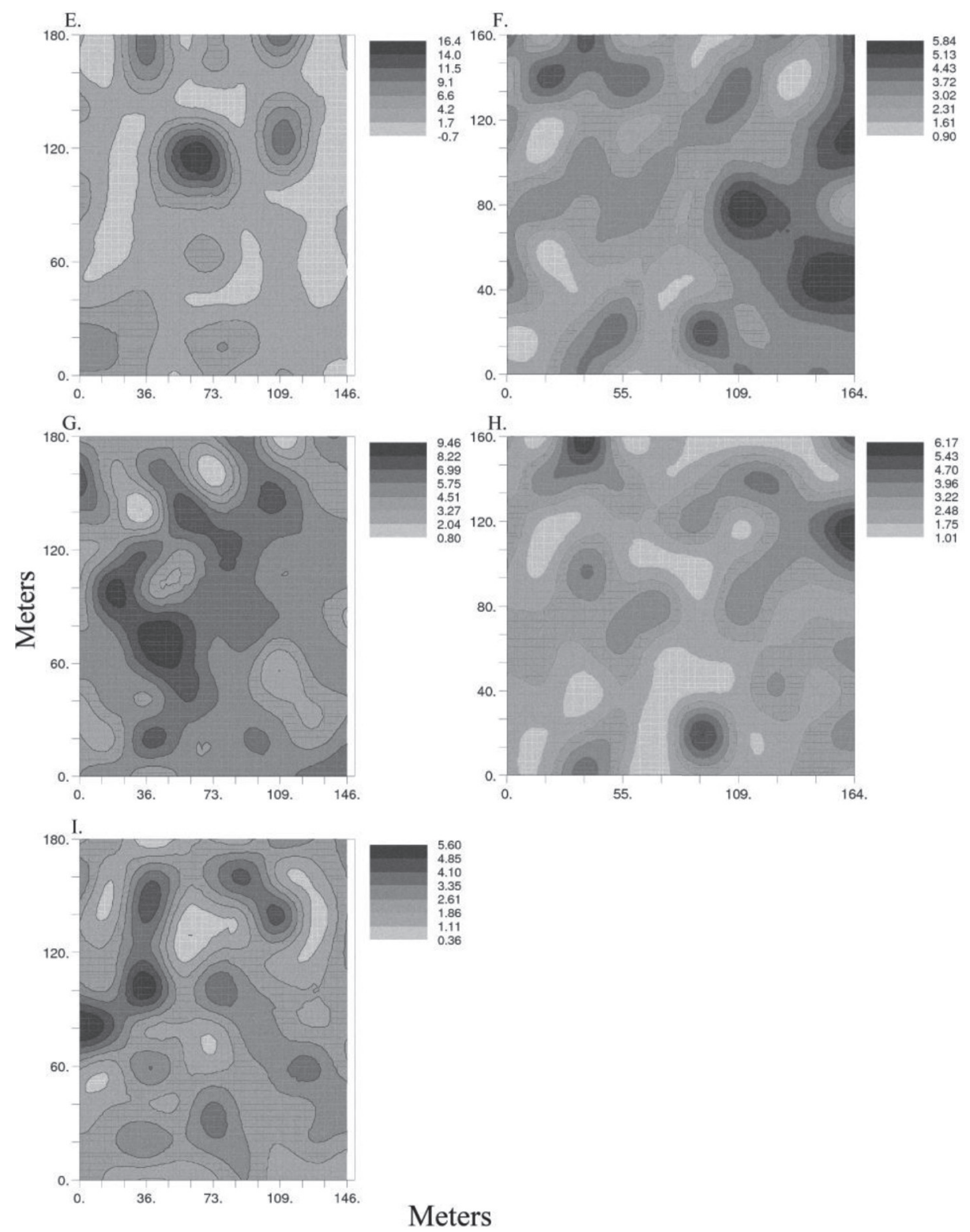

Figure 6 - Maps of the spatial distribution for the variable K (\%) of soil at 0-0.2 and $0.2-0.4 \mathrm{~m}$ in the three soils of crop years 2010 and 2011.

\section{ACKNOWLEDGMENTS}

The authors thank Conselho Nacional de Desenvolvimento Científico e Tecnológico (CNPq) and Coordenação de Aperfeiçoamento de Pessoal de Nível Superior (CAPES) for research grants awarded; and the reviewers and editors for their valuable comments and contributions to improve the manuscript.

\section{RESUMO}

Quando depositada no solo, a vinhaça pode promover melhoria em sua fertilidade, porém, muitas vezes a aplicação de fertilizantes ocorre em áreas consideradas homogêneas, sem levar em conta a variabilidade do solo. O objetivo deste trabalho foi avaliar o efeito da aplicação de vinhaça no teor de potássio em duas classes de solos cultivados com cana-de-açúcar e caracterizar a variabilidade espacial do 
solo utilizando técnicas de geoestatística. No ano/safra de 2010 e 2011 as amostras de solo foram coletadas em malha experimental nas profundidades de 0-0,2 e 0,2-0,4 m em três solos cultivados com cana-de-açúcar, totalizando 90 pontos de amostragem em cada malha, para determinação de $\mathrm{pH}$, cálcio $(\mathrm{Ca})$, magnésio $(\mathrm{Mg})$, potássio $(\mathrm{K})$, fósforo (P), alumínio $(\mathrm{Al})$ e acidez potencial $(\mathrm{H}+\mathrm{Al})$. Os dados foram submetidos às análises de estatística descritiva e o atributo $\mathrm{K}$ foi submetido à análise geoestatística. $\mathrm{O}$ coeficiente de variação indicou média e alta variabilidade de $\mathrm{K}$ nos três solos estudados. Os resultados mostraram que a a dependência espacial do $\mathrm{K}$ aumentou em profundidade para o FRce e diminuiu para o PHlv, indicando que o atributo pode ter seguiu o padrão de distribuição de argila com a profundidade. A investigação da variabilidade espacial do $\mathrm{K}$ na superfície e subsuperfície dos solos proporcionou a definição de zonas de manejo com diferentes níveis de fertilidade, que poderão ser organizadas em subáreas para uma gestão mais eficiente de recursos e do ambiente.

Palavras-chave: Geoestatística, Saccharum officinarum, semivariograma, fertilidade do solo.

\section{REFERENCES}

ANDRADE JMF AND DINIZ KM. 2007. Impactos ambientais da agroindústria da cana-de-açúcar: subsídios para a gestão, 131 p. Trabalho de Conclusão de Curso - Escola Superior de Agricultura "Luiz de Queiroz", Universidade de São Paulo. (Unpublished).

Cambardella CA, Moorman TB, Novak JM, Parkin TB, KARLEN DL, TURCO RF AND KonOPKA AE. 1994. Fieldscale variability of soil properties in central Iowa soils. Soil Sci Soc Am J 58: 1501-1511.

Campos mCC, Marques Júnior J, Pereira GT, Souza ZM AND BARBIERI DM. 2008. Fertilizer and limestone applications after the harvest of sugarcane as determined by geostatistics techniques. Ciênc Rural 38: 974-980.

CARVAlho LA, Meurer I, Silva Junior CA AND CENTURION JF. 2012. Spatial variability of soil physical properties in two management systems in sugarcane crop. Eng Agric 32: 60-68.

CETESB - COMPANHIA de TeCNOlogia de SANEAmento AmBIENTAL. 2006. Norma Técnica - P4.231. Vinhaça Critérios e Procedimentos para Aplicação no Solo Agrícola. $<$ http://www.cetesb.sp.gov.br/Tecnologia/camaras/P4_231. pdf $>$. Accessed 02 October 2011.

CorÁ JE, AraúJo AV, Pereira GT AND Beraldo JMG. 2004. Assessment of spatial variability of soil attributes as a basis for the adoption of precision agriculture in sugarcane plantations. Rev Bras Ciênc Solo 28: 1013-1021.
DALCHIAVON FC, CARVALHO MP, MONTANARI R AND ANDREOTTI M. 2013. Strategy of specification of management areas: rice grain yield as related to soil fertility. Rev Bras Ciên Solo 37: 45-54.

EMBRAPA - EMPRESA BRASILEIRA DE PESQUISA AgROPECUÁRIA. 2005. Manual de Laboratórios: Solo, Água, Nutrição Vegetal, Nutrição Animal e Alimentos. São Carlos: Embrapa Pecuária Sudeste, p. 344.

GonÇALVEs ACA, Folegatti MV AND MATA JDV. 2001. Exploratory and geostatistical analysis of physical properties on a tropical soil. Acta Sci Agron 23: 1149-1157.

GUIMARÃES EC. 2000. Variabilidade espacial de atributos de um Latossolo Vermelho-Escuro textura argilosa da região do cerrado, submetido ao plantio direto e ao plantio convencional. Tese de Doutorado. Campinas, Universidade Estadual de Campinas, 85 p.

ISAAKS EHAND SRIVASTAVA RM. 1989. An Introduction to Applied Geostatistics. New York: Oxford University Press, p. 560.

IUSS Working Group WRB. 2006. World reference base for soil resources. World Soil Reference Report No. 103. FAO, Rome, p. 145.

KoHLHEPP G. 2010. Análise da situação da produção de etanol e biodiesel no Brasil. Estudos Avançados. 24: 223-253.

LEITE GF. 1999. Avaliação econômica da adubação com vinhaça e da adubação mineral de soqueiras de cana-de-açúcar na Usina Monte Alegre Ltda. Un Alfenas 5: 189-191.

MARques JÚNIOR J, SOUZA ZM, PEREIRA GT AND BARBIERI DM. 2008. Spatial variability of organic matter, P, K and $\mathrm{CEC}$ in a long-term sugarcane cultivated Oxisol. Rev Biol Ciênc Terra 8: 143-152.

NiCOCHELLI LM, NESCENTES R, LiMA EBNR AND SOARES FSC. 2012. Sorção de potássio em amostras de solo submetidas à aplicação de vinhaça. Rev Bras Eng Agric Ambient 16: 754-760.

ROBERTSON GP. 1998. GS+: Geostatistics for the environmental sciences: GS+ user's guide. Plainwell: Gamma Design Software, $152 \mathrm{p}$.

SANChez RB, Marques Júnior J, Pereira GT, Souza ZM AND MARTINS FILHO MV. 2009. Variabilidade espacial de atributos do solo e de fatores de erosão em diferentes pedoformas. Bragantia 68: 873-884.

SILVA AJN, CABEDA VSM AND LIMA FWFJ. 2005. Effect of use and management systems on the physical and hydraulic properties of a Yellow Argisol of coastal tablelands. Rev Bras Ciênc Solo 29: 833-842.

SILVA MAS, GRIEBELER NP AND BORGES LC. 2007. Use of stillage and its impact on soil properties and groundwater. Rev Bras Eng Agric Ambient 11: 108-114.

VIEIRA SR. 2000. Geoestatística em estudos de variabilidade espacial do solo. In Novais RF, Alvarez VH, Schaefer CEGR (Eds), Tópicos em ciência do solo. Viçosa: Sociedade Brasileira de Ciência do Solo, p 1-54.

VIEIRA SR, Hatfield JL, NiELSEN DR AND BIGGaR JW. 1983. Geostatistical theory and application to variability of some agronomical properties. Hilgardia 51: 1-75.

WARRICK AW AND NIELSEN DR. 1980. Spatial variability of soil physical in the field. In: Hillel D (Ed), Applications of soil physics. New York: Academic Press, p. 319-344. 
